\title{
The Truth Behind the Legend: European doctors in pre-colonial India
}

\author{
RAJESH KOCHHAR
}

(Source: J. Biosci., 24, No.3, September 1999; 259-268)

\begin{abstract}
The aim of this article is to point out that the medical history of India in the seventeenth century needs to be studied for its bearing on the history of medical science in this country. During the period 1644-1717, European physicians in India were sought and pampered by the Indian ruling class. English doctors were able to translate this professional goodwill into concrete commercial concessions for the British East India Company. The concessions gave the Company an edge over its rivals, and, more importantly, gave it a cause to fight for. In consequence, the Company was transformed from a vaishya (trading) organization into a kshatriya (territorial) one. These conclusions warrant a more rigorous professional study of European doctors vis-a-vis their Indian counterparts in the pre-colonial period.
\end{abstract}

\section{Introduction}

We live in an age of cultural Copernicanism (Kochhar 1999). In cosmology the Copernican principle states that the universe has no preferred location or direction. In a similar fashion, cultural Copernicanism asserts that no cultural, geographical or ethnic area can be deemed to be a benchmark to be used to evaluate and judge others. It is in the framework of cultural Copernicanism that concerted efforts are being made in the world of medicine to identify traditional knowledge systems and accord them the recognition hitherto restricted to the 'mainstream'. That mainstream today is defined by the orthodox practices prevalent in western medicine, while systems like the Ayurvedic and the Unani (known in Europe as the Arabic system) are considered peripheral. India's first encounter with western medicine took place in the mid-seventeenth century, when it had already 'taken off (though rapid progress was to come only in the nineteenth century). This encounter has been remarked on in the context of economic history, but does not seem to have been seriously examined vis-à-vis the history of science. The Ayurvedic and Unani systems on the other hand had, through years of empirical practice, reached more or less a plateau of development. Professionally, how did the traditional systems fare in comparison with the new entrant? I will try to address this important question with a view not so much to providing definitive answers as to bringing the question itself into sharper focus.

\section{Knowledge of Indian medicine in Europe: the story of Garcia d'Orta}

The Europeans brought not only syphilis from their ocean voyages but also new remedies. There was a concerted attempt to incorporate the traditional knowledge of the Americas and the East Indies into the European mainstream. Thus, between 1565-1574 the Spanish physician Nicolas Monads (c. 1493-1588), enthusiastically publicised the therapeutic powers of American drugs. He did not himself travel outside Europe but learnt about American plants from the material brought into Europe. One of the best known of Minaret's plant descriptions was that of tobacco. His work was translated into Italian and English in his own lifetime and after his death into French and German, Europeans were eager to learn about the new remedies; the English translation (1577) was entitled Joyful News out of the New Founde Worlde. Similarly, thanks to the efforts of the Franciscans in Mexico, an account of Aztec medicinal plants accompanied by drawings was got prepared by an Aztec, translated into Latin and sent to Europe (Conrad et al 1998, pp 3067).

Europe's introduction to Indian plants and drugs and to tropical diseases came from the work of the Portuguese physician Garcia d'Orta (1501 or 1502-1568) who came to India in 1534 and remained there till his death (Markham 1913 , p. vii). Before taking up a discussion of his work, it would be appropriate to examine details 
of his life, his intellectual attitude seems to have been moulded by his family background. Orta's parents were Spanish Jews who migrated to Portugal in 1492, when Jews were expelled from Spain. Forced in 1497 to choose between exile and conversion, the family nominally converted to Christianity. Orta was fortunate to find a patron in Dom Fernao de Sousa, "of a noble family descended from a natural son of King Alfonso III by a very beautiful Moor, daughter of the Cadi of Faro" (Markham 1913, p. viii). Orta studied at the Spanish universities of Salamanca and Alcala de Vide from 1515 to 1525 , qualified as a physician in 1526 and worked as a village doctor from 1526 to 1532 . In 1532, thanks to the help of his patrons, he was appointed a lecturer in natural philosophy at the University of Lisbon. He left the job in 1534 to accompany his young patron and friend, Martin Affonso de Sousa, to Goa.

Orta served as physician to the governors of Goa, as also to the ruler Burham Nizam Shah whose capital was in Ahmadnagar. He had a house and garden with many medicinal herbs at Goa, and in about 1554 he was granted a long lease of (part of) the island of Bombay, which he sublet.... He knew personally all the plants within his reach from which drugs were derived. For the rest he was indefatigable in his enquiries from native physicians, and in his examination of Yogis from the kingdoms of Delhi, and of traders and others from all parts - "Deccanis, Guzeratis, Bengalis, Cingalese, Moors, Persians, Arabs and Malays". He was assisted in his work by "his intelligent Konkani servant girl Antonia" (Markham 1913, p.ix).

Orta played host to the immortal Portuguese poet Luis Camoens, who came to Goa in 1561. The poet passed many agreeable and instructive hours in the house of the learned old man, admiring his collections and examining his extensive library, finding in both materials for the last two cantos of Os Lusiados. While in Goa, Camoens composed a sonnet on Orta, playing on his name which also means garden. The sonnet closes with the line (loosely translated) "Taught of yore by the muses of Ganges and Ind, full of learning, as of years, in all that is known of the true healing art, old Chiron must bow before thee".

In 1563, Orta wrote his influential book in Portuguese whose title translates as Colloquies on the Simples, Drugs and Materia Medica of India. It was the third book to be printed in Goa and India. It was preceded by religious texts a Catechism by St Francis Xavier (1557) and a
Compendia espirituel by $\mathrm{Dr}$ Pereira, the first archbishop of Goa (1561). The work contains chapters on fifty seven drugs and simples. Among other things, it describes the effects of bhang (cannabis) and furnishes Europe with first account of treatment of a case of cholera. In addition, there is much interesting matter, for example, on the fights between the cobra and mongoose, and the etiquette of chewing betel nut (Markham 1913, p. 195).

The format used by Orta for his book is significant. It is in the form of a dialogue between two persons. One of them, the questioner, is a fictitious character, Dr Ruano, who had studied at Orta's alma mater, Salamanca, and is very much a man of the school, erudite and ready with quotations. Ruano is probably what Orta was in his younger, bookish days. The answerer is the maturer Orta, traveller and observer, perpetual learner and pluralist, who rejects received wisdom in favour of empirical knowledge "For me the testimony of an eye-witness is worth more than that of all the physicians, and all the fathers of medicine who wrote on false information". In a similar vein, he tells Ruano, "Do not try to frighten me with Dioscorides or Galen, because I merely speak the truth and say what I know" (Markham 1913, p. 68).

It is of interest to see what Orta had to say on tamarind (especially because patents on tamarind have recently been granted in the USA). Tamarind is a produce, special to India, as can be seen from the name itself. The name is derived from the Arabic/Persian Tamar-eHind, or Indian date, which was coined by traders. Tamarind was sent out from the Indian west coast to Cairo from where it was taken to Alexandria and then Venice for use in Europe. It was not known to the ancient Greeks. It is mentioned by Yuhanna bin Masawayh (777857), the celebrated Persian-Christian physician who attended on four caliphs at Baghdad. He is Ruano's authority on tamarind: "Mesue, who is so much admired by his Arabian imitators, says that they (tamarinds) are from the wild palms of India". No doubt, Masawayh's description was based on a paraphrase of tamarind's name. But, as Orta explained, "It is not a kind of date, nor has it the form of a date tree, except that both have stone". Mesue, declared Orta, "does not know what he is talking about". Describing tamarind first hand thus provides Orta with an opportunity to debunk old authorities, because as he says, "even I, when in Spain, did not dare 
to say anything against Galen or the Greeks" (Markham 1913, p. 275).

Orta's personal history as a hidden Jew who had to use Christianity as a mask for survival was probably responsible for creating a mindset that rejected the weight of authority in favour of direct evidence. Europe was ready for his information but not for his historiography. In 1567, a Finnish botanist L'Ecluse extracted the essential information on the characteristics and properties of the economic and medicinal plants of India, and published an epitome in Latin (Markham 1913, p. xv). It is this epitome, rather than the original Colloquies, which was translated into Italian (1582) and French (1619). Similarly, a Spanish work published in 1578 by another converted Portuguese Jew, Christovas da Costa, describing sixty-nine plants and other sources of drugs and medicines, is "copied wholesale from Orta". The great merit of Costa's works is that it includes well-drawn full-page illustrations of forty-six plants with roots. The standard edition of Orta's work, edited and annotated by an accomplished botanist. Count Ficalho, appeared as late as 1891 and 1895 (in two volumes) by which time Orta's historiography had become self-evident. It was translated into English in 1913 by Sir Clements Markham, who is the source of most of the above information on Orta.

By the circumstance of his geographical location and professional activity, Orta's plant knowledge had "an unwilling bias towards Muslim systems". A hundred years after Orta, Malayali sources were tapped by a Dutchman Hendrik Adriaan van Reede tot Drakenstein (1636-1691), the governor of Dutch territories in Malabar, and himself the son of a chief forester in the Netherlands. Like Orta before him, "van Reede went through the same process of rejecting Arabic classification and nomenclature and European knowledge in favour of a more rigorous adherence to local system of classification". For his information, he depended on the members of the Ezhava community of toddy-tappers, who were "adept both at tree climbing and plant identification". More particularly, van Reede consulted the Vaidyars, the traditional Ayurvedic physicians with an extensive, time-tested knowledge of the medicinal value of plants. His chief helper was a Vaidyar named Itti Achuden (Grove 1996, pp 8586). Van Reede's magnum opus, the 12-volume Hortus Malabaricus, was published from Amsterdam during the period 1686-1703. It described about 780 species of plants, supported by 794 illustrations. This and other similar work in the East Indies established Holland as a centre for tropical botany, and would provide Karl von Linne (Linnaeus) (17071778 ) with the source material for his binomial system of taxonomy (1735). Thus "in the process of empire building, India was added as a laboratory to the edifice of modern science" (Kochhar 1992, p. 694).

\section{Medical problems elsewhere}

We have a first-hand account of medical practice in Iran in the late seventeenth century written by a professional English physician. Presumably the account would apply to India as well because the Indian nobility of the time was partially derived from Iran. The author is John Fryer (c. 1650-1733), an M.B. from Cambridge and "a skillful and experienced artist in that profession". He joined the British East India Company's service in 1672 and was in the east from 1673 to 1681 ; during 1677-1679 he was in Iran; and otherwise at Surat and Bombay. Fryer returned to England in 1682, and the next year obtained an M.D. from Cambridge. He was elected a fellow of the Royal Society in 1697, becoming its first India-connected fellow and retained the fellowship until 1707 . In 1698, he published a valuable book on his travels, called A new account of East India and Persia in Eight Letters, begun 1672 and finished 1681. Fryer notes that a Dr NG (from India) sent an account of the manufacture of ghee (clarified butter) to the Royal Society (Elgood 1951, p. 397; Crawford 1914 I, pp 66-7). However, far more significant is his description of the medical system in Iran, which is excerpted below in rearranged form (Elgood 1951, pp 401-5).

"The fashionable Malady of this Country is a Clap, scarce One in Ten being free from it; which the unbounded Liberty of Women, Cheapness of the Commodity, and the encouragement of their filthy Law, are main Incentives to. The Poyson creeps into the Marrow of their Bones, so that they are not come to Maturity, before they are rotten; though by reason of the Pureness of the Air, it seldom or never arrives to that height of Cruelty as in Europe; inasmuch as when they are so dealt by it, they reproach it with the Frank Disease, Atecheque Fringi, when it breaks out into Sores and Ulcers, after it has seized the whole Mass of Blood, and eats them up alive; while they wear theirs dormant almost to extreme Old Age, which makes them not much solicitous for 
Remedy, nor are there any who profess its Cure".

Fryer goes on to describe other ailments "Most of them by a Fullness of Body are subjected to Hemorrhoids; but what chiefly vexes them . . . is a Fistula in Ano, which they contract from their Athletick Temper, and constant being on Horseback. Nor does it seldom fall out, from their aptness to Venery, and proneness to make use of Boys, that they are afflicted with terrible Mariscae, or swoln Piles of several forms, by them called Obne. . $\therefore$.

"The Plague has not been known among them this Eighty Years and upwards, but the Spotted Fever kills them presently. The Gout afflicts few here, the Pox commonly securing them from it . Physick; which though it be here in good Repute, yet its Sectators are too much wedded to Antiquity, not being at all addicted to find out its Improvement by new Enquiries; wherefore they stick to the Arabian Method as devoutly as to the Sacred Tripod, which they hold as Infallible as of old that Delphic Oracle was accounted".

"On which score Chemistry is hardly embraced; nor to the Pathological part do they think the Anatomical Knife can bring much Profit".

"Any one who wished to join the profession took instruction from a master, and then set up his practice where there were the fewest physicians already. His fame spread by degrees which in turn brought in many students. If the physician failed to set up a successful practice, he would "fall upon other Trades to get a Livelyhood".

"In the matter of their Physick, Extracts or Essences of Plants, Roots, or Minerals, are beyond their Pharmacy; only they use cooling Seeds, and medicines of that nature". "Rhabarb, Turbith, and Scammony are dreadful to them; but Senna, Cassia, Manna, and Turpentine are swallowed without any apprehension of evil. Many of their Physicians insist on diet unusual elsewhere, as Goatsflesh, Horses, Asses, and Camels flesh; for which reason they have distinct Shambles for the same purpose" ... "Avicen, Averroes, and Rhasis are known Authors among them; and among the most Learned, Galen and Hippocrates, and some more Modern, who have treated of Botany and Human parts".

The patient would consult a physician "for a Fortnight or Three Weeks together; which if it succeed not, another Physician is consulted; for among such store they think it hard to miss a Cure; and in that they are so opinionated, that if their own Nation cannot give them a Remedy, they think none other can. (Though as to Chyrurgery, they are of another mind, thinking the Europeans better at Manual Operation than themselves.)"

\section{Variolation}

Whereas the above medical report on Iran written by a physician remained a historical curiosity, a layperson's account from Turkey had a great impact on Europe's public health. Smallpox was a major killer in Europe, especially of children. Asia however had a method of protection against it. The method was variolation, an inoculation of a healthy individual with true smallpox, which produces a milder attack than spontaneous infection does and confers immunity on the individual against future attacks.

Europe learnt about variolation from its correspondents in Istanbul. Emmanuel Timoni's account in 1714 in the prestigious Philosophical Transactions of the Royal Society of London went largely unnoticed. But the medicoadministrative establishment took note when Lady Mary Wortley Montagu (1689-1762), the wife of the British consul, described how Turkish peasant women carried out the inoculation. In her childhood Montagu had been severely affected by smallpox. Now, she got her five-year-old daughter inoculated. The soon-tobe king George II followed suit with his two daughters. The practice caught on in Europe, at least among royalty, with Catherine the Great paying an English surgeon as much as $£$ 10,000 for her family's inoculation.

As far as the masses were concerned, there was need for bulk inoculation in order, to prevent the spread of infection to un-inoculated people. Bulk inoculation was easy to carry out in villages rather than in the cities, where mortality remained high.

"A learned and judicious ornament of the (London) College of Physicians" writing before 1757 paid a left- handed compliment: "That the Art of Medicine has, in several instances, been greatly indebted to accident; and that some of its most valuable improvements have been received from the hands of ignorance and

\footnotetext{
${ }^{1}$ Based on Ackerknecht (1982, pp 142-3) and Conrad et al (1998, pp 431-3).
} 
barbarism; a truth, remarkably, exemplified in the practice of inoculation of the small pox".

The above comment is taken from An account of the manner of Inoculating for the Smallpox in the East Indies. With some observations on the Practice and Mode of Treating that Disease in those parts. Inscribed to the [earned, the President and Members of the College of : Physicians in London (Crawford 1914 I, p. 176; Dharampal 1983, p. 196). Published in 1757, it was written by John Zephania Holwell (17111798) who studied surgery ; at Guy's hospital and served in Bengal from 1732 till 1760. Responding to the above, Holwell wrote "nearly the same salutary method, now so happily pursued in England (howsoever it has been seemingly blundered upon), has the sanction of remotest antiquity". Holwell then proceeded to describe inoculation as he himself had observed it (Dharampal 1983, pp 196, 201-4).

"The inhabitants of Bengal, knowing the usual time when the inoculating Brahmins annually return, observe strictly the regimen enjoined . . .; this preparation consists. only in abstaining for a month from fish, milk, and ghee; the prohibition of fish respects only the native Portuguese and Mahomedans, who abound in every province of the empire. When the Brahmins begin to inoculate, they pass from house to house and operate at the door ... ."

"The instrument they make use of, is of iron, about four inches and a half long, and of the size of a large crow quill, the middle is twisted, and the one end is steeled and flatted about an inch from the extremity, and the eighth of an inch broad; this extremity is brought to a very keen edge, and two sharp corners; the other end of the instrument is an earpicker, and the instrument is precisely the same as the Barbers of Indostan use to cut the nails, and depurate the ears of their customers

"The inoculation was generally given on the outside of the arm, between the wrist and the elbow. The chosen spot was rubbed with a dry cloth for 8-10 $\mathrm{min}$. "The Operator of inoculation holds the instrument as we hold a pen, and with dextrous expedition gives about 15 or $16 \mathrm{~min}$ scarifications within the compass 'of a silver groat' with one of the sharp corners of the instrument, just making the smallest appearance of blood, then opening a linen double rag (which he always keeps in a cloth round his waist) takes from thence a small pledgit of cotton charged with the variolous matter, which he moistens with two or three drops of the Ganges water, and applies to the wound, fixing it on with slight bandage, and ordering it to remain on for 6 $h$ without being moved, then the bandage to be taken off, and then the pledgit to remain until it falls itself . . . from the time he begins the dry friction, to tying the knot of the bandage, he never ceases reciting some portions of the worship appointed by the Aughtorrah Bade, . . . "Significantly," the cotton, which he preserves in a double callico rag, is saturated with matter from the inoculated pustules of the preceding year, for they never, inoculate with fresh matter, not with matter from the disease caught in the natural way, however distinct and mild the species". The whole procedure was obviously quite successful, because "it is next to a miracle to hear that one in a million fails of receiving the infection, or of one that miscarries under it."

Those were the days when the full British control of India was yet to come; the number of British in India was small; their interaction with the upper crust of the native society was quite cordial; and they had a genuine respect for and curiosity about things Indian. Thus, Dr Helenus Scott, M.D. (1760-1821) who served in Bombay for thirty years, wrote, in 1792, to the president of the Royal Society London (Dharampal 1983, pp 312-3).

"In medicine I shall not be able to praise their science very much. It is one of those arts which is too delicate in its nature to bear war and oppression and the revolutions of governments. The effects of surgical operations are more obvious, more easily acquired and lost by no means so readily. Here I should have much to praise. They practice with great success the operation of depressing the chrystalline lens when become opaque, and from time immemorial they have cut for the stone at the same place which they now do in Europe. These are curious facts and I believe unknown before to us". (This may be compared with Fryer's statement quoted above that the Iranians considered Europeans to be better surgeons than themselves.)

Returning to smallpox, we do not know what reception Holwell's 1767 account got back at home. After about eighty years of sporadic and controversial use of variolation in Europe, a better method was discovered in 1796 by Edward Jenner (1749-1823). A country physician, Jenner observed that infection with cowpox gave milkmaids immunity against the far more dangerous smallpox, and sagaciously transformed this observation into the medical technique of vaccination, that is inoculation not 
with the true smallpox virus but with the cowpox. Vaccination was introduced into India in 1802, and the earlier sympathy for the traditional inoculation made way for hostility and derision (Harrison 1994, p. 82).

The above accounts on non-western medicine were written by Europeans. We shall presently discuss the role of European doctors in India. It would however be useful to first set the background by reviewing the early years of the East India Company.

\section{European traders in India}

Ships of the (British) East India Company first arrived in India in 1608 at the western port of Surat and immediately set out to establish their naval superiority over the Portuguese who had arrived a hundred years previously. The Company moved into Bengal in 1651 with the establishment of a factory (warehouse-cumresidence) at Hughli. The same year it obtained a nishan (an official order) from the Mughal governor granting exemption from payment of custom duties.

These exemptions gave the British traders a decided commercial advantage over other European companies and even over native traders. More importantly, the various official orders granting trade concessions gave the British a cause to defend, with military strength if needed. Indeed, the transformation of the Company from a vaishya (trading) outfit into a kshatriya (territorial) organization was brought about by its desire to enforce its own version of the official charters issued in its favour and to continue with their misuse. It must be said, however, that on their part the Mughal functionaries, from the head of the province downwards, tended to treat the European traders as milch cows.

In 1686, the Company (with the permission of James II) launched a premature military offensive against the Mughals and as a result got expelled from Bengal. The expulsion was temporary. The British trading presence on land was good for the Mughal economy and the British presence in the waters a check against the Portuguese and pirates. In August 1690, under the leadership of Job Charnock, "the English once more settled at Sutanati (down the river Hughli) and erected a few huts that were destined to grow into the capital of their Indian empire". In 1696, the Calcutta settlement was fortified under the name Fort William. At that time, the subahdar of Bengal was the weak and old Ibrahim Khan. To the British, he was "the most famously just and good Nawab". A Muslim historian, using irony, said of him that "he did not allow even an ant to be oppressed". In 1698, the Company secured the official zamindari rights (that is, the right of revenue and tax collection) of the three neighbouring villages Kalikata, Sutanati and Govindpur. Literary texts of the period as well as a Dutch map dated 1660 drawn by van den Broucke mention Kalikata and Kalighat as two separate entities. Although the new settlement originally came up at Sutanati, it was named after the neighbouring village of Kalikata. The idea probably was to cash on the similarity of the name (later to become Calcutta) with Calicut, already well-known in Europe from Portuguese trade (Ray 1986, pp 5, 13, 15).

The first half of the eighteenth century saw the restoration of firm rule in Bengal under the Nawabs, from Murshid Quli Khan to Alivardi Khan. During this period, the British remained under check. After Alivardi's death came the 1757 battle of Plassey, after winning which the Company did not have to worry about trade concessions. It could take over the whole revenue of the state and then the state itself.

\section{European medical men in India}

Attracted by new opportunities and assured by the European presence there, many European physicians, self-taught and learned, moved eastwards. The most interesting example from the self-taught category comes not from India but Iran. The East India Company opened its first factory in Iran at Isfahan in 1616 (under the control of Surat). A Catholic Scotsman, George Strachan (Elgood 1957 pp 393-5; Crawford 1914 I, pp 59-60), was surgeon to the factory from 1619 to 1621 . "His life was a strange one. In 1602 he was in Rome, where he entered the Scots College, but apparently never reached even minor orders". A desire to travel took him to Istanbul (1612) and from there to Syria, Lebanon, and then to Aleppo (about 1615). Here he heard that the Amir of Anayza was in need of a physician. "With the earlier motive perfecting his Arabic, he took service with him, although he was at the moment entirely ignorant of medicine". However, he furnished himself with some prescriptions from a Flemish doctor, bought a book or two and started to practise. He was enormously successful. He was in such favour with the Amir that he was married to the Amir's sister (according to 
another version the woman was the widow of the Amir's brother). In 1618, Strachan fled to Baghdad to avoid conversion, and from there moved to Isfahan, where he was hired by the Company as a surgeon and linguist. $\mathrm{He}$ was charged with embezzlement and murder, dismissed in 1620 and reinstated the next year, though only temporarily. Strachan remained in Iran till the end of 1622 or early 1623. About the rest of his life nothing is known, except that he intended to return to Europe.

As varied, but less exciting, was the career of Nicholas Manucci (1639-c. 1717) who left Venice for the East Indies at an early age of fourteen. He took service with an English traveller. Lord Bellamont; in what capacity is not recorded. In 1656 Manucci came to Delhi and worked as the Mughal Emperor Shahjahan's son Dara Shikoh's artilleryman at a monthly salary of 80 rupees. After Dara's murder in 1659 , "he adopted medicine as a profession, apparently without any training or knowledge, at Agra". During 1664-1665, he served as a captain of artillery in the Deccan, under Mirza Raja Jai Singh (an ancestor of Raja Jai Singh Sawai, the astronomer). During 1671-78, Manucci practiced medicine in Lahore and then, during 1678-82, served as physician to Shah Alam, the eldest son of Aurungzeb. He arrived in Madras in 1686 and remained here for the next 30 years till his death. ${ }^{*}$

In contrast to Strachan and Manucci stands Francois Bernier (1620-1688) who had a formal degree, an M.D. from Montpellier. Arriving in India in 1658 or 1659 , he served for a while as a surgeon to Dara Shikoh and then to his brother Aurungzeb. Bernier returned to Europe in 1667 through Persia. Both Bernier and Manucci are well- known for their historical accounts. Bernier's Travels is a valuable source of information while Manucci's "wonderful narrative" Storia do Mogor or Mughal India is "less reliable and more discursive".

In his work, Manucci mentioned several other European surgeons in India. An Armenian, called Sikandar ) Beg, was surgeon to Suleiman Shikoh, Dara's eldest son, ;e in 1658. A Dutch surgeon, Jacob Minues, was in Agra in 1663, and had fled Goa after killing a man there. Another Dutch surgeon, Gelmer Vorburg, was in Assam the same year. Other names are Luis Beicao with Mirza Raja Jai Singh in the Deccan (1664); a Venetian, Angello Legrenzi, in the court of Shah Alam at Aurungabad (1679); D'Estremon, with the sultan of Golconda (1684); and a Frenchman, Cattem, in Bengal (1700).
From Tavernier, we learn about a French physician, Francois de. la Palisse, alias St Jacques, as being at the Mughal court; and Claudius Malle, of Bourges, as surgeon to the governor of Allahabad, both about 1666. The Company tried to draw on their help. In 1684 the Company asked D'Estremon Golconda for help in obtaining a farman, a Royal edict, that would permit the Company to coin rupees. Similarly in 1693, Johannes Petuliet ("from his name probably an Armenian") who was physician to the Nawab of Carnatic "tried to help the English get a. farman from the Emperor at Delhi for free trade on the Coromandel coast".

In the final analysis, however, the trading concessions that the Company procured were obtained through the good offices of its own surgeons. It was obligatory for the Company ships to carry a priest on board if the tonnage was larger than 5-00 tons. The Company considered a priest to be an unnecessary item of expenditure and routinely listed its ships at 499 tons. It was obligatory, and this time also necessary, to carry a surgeon. In 1614, the Company appointed a surgeon-general, John Woodall, whose task was to provide surgeons for the ships. Woodall was a member of the London Company of Barber Surgeons. As already noted, those were the days when barbers and surgeons were clubbed together because of their professional requirements of the same instruments. Woodall was also a surgeon at the St Bartholomew's hospital. Many complaints were made about the incompetence of the men chosen by Woodall. He seems to have appointed his own apprentices to serve on ships at a nominal wage, while he himself as their employer drew the greater part of their pay in London. After Woodall's death in 1643, another surgeon, Henry Boone, was employed in much the same capacity (Crawford 1914 I, p. 26). While the general level of ship surgeons might have been low, there were apparently some who were quite competent.

At the time there was hardly anything to choose between an Indian physician and a European one. A request from the Isfahan factory in 1638 for a doctor was refused on the grounds that "fevers and fluxes, both in India and Persia, are most familiarly cured by natives of each or either, to whome nor means nor skill is wanting".

It is however significant that Surat promised to send "any physic, unguents, or plasters required". The presence of a European surgeon at Surat was a great help to the neighbourhood. 
In 1636, the president of the Surat factory recorded "A young Bramene about the age of 14 years, washing himself in the river not far from the customhouse, a fish or crocodile (I conceave rather a sharke) sheared off his right arm in the midst betwixt the elbows and shoulder; who being the only child of his mother, a poor widow, I commanded the surgion to undertake the care for God's sake; who sawed off the boone, being shattered, and clipping of some torn flesh and then, applying such powders and other means as the case required, he bound it up very hard to stop the bleeding, all which the boy indured with manlike patience". Another case occurred ten days later. It involved a "Banian called Cullian Vesse (Kalyan Vaishya) . . . an undertaker betwixt the rustickes and the Governor concerning the payment of their rents, who had received a great wound upon his head and another upon his leg". The surgeon, called at about ten at night, "used his best meanes", but "before midnight the Banian dyed".

However, the most notable name in the Company's medical annals is not the doctor who attended on the local populace but the one who served the Mughal nobility. "No stone marks his resting place, no memorial to him is in existence - But History records his services to the Company and to his country". "One of the most widely known stories of the early history of the English in India is the legend of Gabriel Boughton (Crawford 1914 I, pp 37,57)".

\section{The legend versus the truth}

The legend held sway throughout the extended 19th century, that is from 1775 to 1910 . During this period it appeared in so many otherwise scholarly publications that it came to be accepted as one of the romances of history. When truth is stranger than fiction, it speaks for itself. When truth is unspectacular or unsavoury, it asks legend to drive home the point. The legend of Boughton (Crawford 1914 I, pp 37-57) is an instance of this. It was first subjected to historical scrutiny in 1911 by Sir William Foster, who was historiographer to the India Office, the repository, of the Company's records and archives. The legend first appeared in print in 1778 in the second volume of Robert Orme's History of the Military Transactions of the British Nation in Industan, from the year MDCCXLV. Here the account given is very brief. A more detailed and picturesque account appeared in 1813 in Major Charles Stewert's History of
Bengal. Stewart's account mixes up dates and names, but its essence is as follows.

Emperor Shahjahan's daughter was "dreadfully burnt" in an accident he desired "the assistance of an European Surgeon. Mr Gabriel Boughton from Surat "immediately proceeded to the Emperor's camp" and "had the good fortune to cure the young Princess of the effects of her accident. Mr Boughton, in consequence, became a great favourite at court; and having been desired to name his reward, he, with that liberality which characterizes Britons, sought not for any private emolument; but solicited that his nation might have liberty to trade, free of all duties, to Bengal, and to establish factories in that country. His request was complied with, and he was furnished with the means of travelling across the country to Bengal. Upon his arrival in that province, he proceeded to Pipley, and in the year 1048 (AD 1638) an English ship happening to arrive in that port, he, in virtue of the Emperor's firman and the privileges granted to him, negociated the whole of the concerns of that vessel without the payment of any duties."

While referring to the Emperor's farman in the above, Stewart added a footnote "I was not able to find a copy of this firman among the Indian records, but Mr Bruce mentions that it is in the State paper office and is dated Feb. 2nd 1634". (J Bruce wrote in 1810 a work called Annals of the East India Company.) Foster remarks that "No such document appears to be in existence". This is significant, because the emperor's farman seems to have been a myth created to derive commercial benefit. Stewart's account continues "In the following year the Prince Shuja having taken possession of the Government, Mr Boughton proceeded to Rajmahal, to pay his respect to his Royal Highness; he was most graciously received; and one of the ladies of the harem being then indisposed with a complaint in her side, the English Surgeon was again employed, and had the good fortune to accelerate her recovery. Owing to this event, $\mathrm{Mr}$ Boughton was held in high estimation at the court of Rajmahal; and by his influence with the Prince, was enabled to carrying into effect the orders of the Emperor, which might otherwise have been cavilled at, or, by some underhand method, have been rendered nugatory". For the next hundred years, this legend, with various modifications, was repeated in many publications some of which were quite influential in their day.

What is the primary source material on which this legend was based? Was the material 
intrinsically defective, or was it deliberately distorted. Fortunately, it is now possible to answer these questions. There are extant two accounts written in the seventeenth century itself which give some details. The oldest record is a manuscript prepared by Thomas Bowrey, captain of a Company ship who was in India during 1670-1680. His work entitled A Geographical account of countries round the Bay of Bengal, 1669-1670 was edited and published in 1905. The second source is a document prepared in February 1685 by John Beard, who became Agent in Bengal in October 1684 and died at Hughli in August 1685. The document is called A Brief Account of the Rice (sic, should be Rise) and Tenor of the Honourable English East India Companies priviledges together (with) their losses of them and their present Case as to the Customs. Beard seems to have been the source for both Orme and Stewart, but they have followed him selectively. Bowrey's and Beard's accounts are in agreement on some points but diverge on others. They need to be examined in the light of other available evidence. The sequence of events can now be reconstructed with reasonable confidence.

In 1643 (or 1644), Emperor's daughter Jahanara met with an accident. "It happened one night while engaged in suchlike dances that the thin raiment, steeped in perfumed oils, of the Princess's favourite dancing woman caught fire, and from the great love she bore to her, the Princess came to her aid, and thus was burnt herself on the chest". This happened at Agra. "Anitulla, the most famous physician of the age, was brought express from Lahore", and the Princess was cured. No European surgeon was involved in this and there was thus no question of Shahjahan's rewarding the Company by issuance of a duty-exemption farman Shahjahan did issue a farman, granting exemption from rahdari, that is road duties, for goods purchased for export via Surat (Chaudhuri 1970, p. 288), but that was much later, in 1650.

The Mughal administration as well as the peripheral kingdoms were fully aware of the benefits European trade bestowed on the economy in general and on high functionaries personally. Permission to open factories was given as a matter of course, and the Mughals routinely gave rahdari exemptions (Prakash 1998 , p. 125). In reality these exemptions did not mean much, because irrespective of the higher orders, bribes had to be paid at the lower levels. Moreover, any concession that was available across the board to all competitors still kept the playing field level. What the British were looking for were concessions that would give them an edge over others. They soon got their chance.

Boughton arrived in Surat in 1644, nearabouts the time of Jahanara's accident and found an attractive appointment waiting for him. Asalat. Khan, mir bakshi (or paymaster general) of the Mughal empire and a special favourite of emperor Shahjahan, had been keen to obtain the services of a European surgeon and had asked the Company at Surat to send him one. Boughton accepted the appointment and came to Agra early 1645 . The next year he even accompanied his patron to Balkh. At about the same time, in Basra, the Company surgeon was providing medical assistance to "the Governour's kinsman and ally Agha" (Crawford 1914 I, p. 66). On Asalat Khan's death in 1647, Boughton accepted the patronage of Shah Shuja, emperor's son and the subahdar (governor) of Bengal and moved to Rajmahal. "One of the princes (sic) concubines, which woman the Prince greatly loved, had a great pain in her side, and could find no cure". The lady was cured by Mr Boughton "in a very short time". In return, according to Beard's 1685 account, two nishans were indeed issued by Shuja granting duty exemption. The duty exemption however was for the surgeon's personal trade and not the Company's. It was through a misuse of these nishans that "a profitable trade was opened in the rich province of Bengal",

Boughton informed Surat about "all goods and merchandise that he could learn were there to be had". Two years later (that would be 1649) a ship arrived from London (under Captain Brookhaven) and bought severals goods free of duties "upon the account of Mr Boughton's nishauns". The British returned two years later, this time to set up a factory at Hughli in Bengal itself and, more importantly, to obtain a nishan in the name of the Company. It appears that while obtaining the 1651 nishan from Shah Shuja, the English traders told him a lie about the nature of Shahjahan's farman issued the previous year. The lie consisted in claiming that the farman had already granted exemption from custom duty whereas it had done nothing more than grant exemption from payment of transit duties (Prakash 1985, p. 75).

It is likely that the elaborate myth-making about Boughton's self-negation and Shahjahan's path-breaking farman was a defensive exercise meant to hide the misuse of Boughton's 
personal privilege and misrepresentation about the farman. The fact however remains that the British commercial foothold in Bengal came about as a result of an English surgeon's good equation with a Mughal subahdar.

\section{Later concessions}

The British traders were not the only ones trying to pull strings in the Mughal capital. In 1711, a Dutch embassy arrived from Surat to the court of Aurungzeb's successor, Bahadur Shah. Their helper in the court was a Portuguese lady, Donna Juliana Dias da Costa, whose late father had been a doctor in the service of Aurungzeb and Bahadur Shah. She held the well-paid job of the "governess of the harem and commanded influence both over the Emperor and his Court". Her efforts however were nulled by the fastchanging political scene. She helped the Dutch get a favourable farman from Bahadur Shah, who unfortunately died soon thereafter of old age. She did manage to get a new farman from his successor, Jahandar Shah; but he lost his throne and life within a year, making way for Farrukh-siyar, the benefactor of the British (Sharma (n.d.), p. 370).

In 1715, a Company embassy came to Farrukh-siyar's court from Calcutta. The embassy included a surgeon, William Hamilton. Within three weeks of arrival in Delhi, Hamilton was "called in to treat Taqarab Khan (the khansama or lord steward), but found his case hopeless. In August (1715) he was required to treat the King for swellings in the groin. and did so with success Two months later, in October, the King was again attacked by violent pain, and it was feared that he would develop fistula. Hamilton's treatment was again successful, and on 7th December the King's marriage to the daughter of Raja Ajit Singh of Jodhpur which had long been delayed by his illness, was celebrated. Hamilton was richly rewarded, receiving an elephant, a horse, five thousand rupees in money, two diamond rings, a jewelled aigrette, a set of gold buttons, and models of all his instruments in gold". Interestingly, reward was also given to the King's French physician, Martin. Martin had joined service with Farrukhsiyar's predecessor and later continued with his successor also.

More important than the personal enrichment of Hamilton was the fact that his professional success placed the Company's embassy in high regard in the emperor's court. In April 1717, the emperor's farman was issued, meeting all the demands that the Company had made in its petitions. It is interesting that after issuing the farman, and not before it, Farrukh-siyar expressed a wish to retain Hamilton in Delhi as his personal surgeon. "As Hamilton was unwilling to stay, much further trouble and delay were caused; but finally Farrukh Siyar consented to let him go, on his promising to return to Delhi, after a visit to Europe". This was not to be, because Hamilton died the same year, in December 1717, at Calcutta. A British medical historian commenting on the above in 1914 wrote patronisingly "the King's consent to his (Hamilton's) departure shows a more reasonable and more kindly disposition than might have been expected in an Oriental potentate" (Crawford 1914 I, p. 120).

Given the chaotic condition of the Mughal empire, Farrukh-siyar's farman giving concessions to the Company was unenforceable, at least in Bengal. Still, it was an important milestone in the Company's quest for the ever-needed legitimacy to support its actions and plans.

\section{Discussion}

We have seen how in 1651 and 1717 the East India Company was able to get trade concessions through the professional services of European doctors. We have also seen that European doctors were sought by noblemen not only in India but also in its northwestern neighbourhood. This raises a number of important questions. Why were European doctors sought and pampered? Was seventeenth century European medicine as a body superior to the Unani and the Ayurvedic systems, so that a typical product of the western system would be superior to his Indian counterpart? Or, were the India-based European men of medicine atypical in the sense that their personal merit transcended the limitations of their background? Or, were they valued not because they were extraordinary professionally but because they were exotic? These questions do not seem to have been adequately addressed so far.

Throughout its existence, the East India Company generated a large number of documents which have been well preserved. The documents have been utilized to compile specific narrative histories. Thus we have A History of the Indian Medical Service 1600-1913 written by DG Crawford and published in two volumes in 1914, Much of the narrative 
information given above is taken from it. Unfortunately, specific information that would be relevant for the discussion at hand is difficult to come by. We would like to know what sort of training India-based European doctors had received in their homelands. What were the ailments their patients reported and how were they treated? What sort of medicines did the doctors prescribe and how and by whom were their prescriptions filled? Even in the case of famous Company surgeons such as Boughton and Hamilton, nothing is known about their professional training. Nor do we know anything worthwhile about the medical history of their well- connected patients, except such vague symptoms as "great pain in her side" or "swellings in the groin". We know nothing of the line of treatment that proved successful for the patients and far-reaching for the British traders. The situation is much worse in the case of European doctors who came into India independently of the Company, some of whose names are mentioned by Manucci and Tavernier. Their names are the only thing we know about them.

The purpose of this essay is to draw attention to the important question of the status of the seventeenth century European medicine vis-àvis its Indian counterparts. It is possible that medical details are scattered here and there in publications or buried in archives. Mughal and other native archives may contain some details of medical advice rendered by the European doctors. Also, letters from these doctors may be extant in European archives. It would indeed be a worthwhile exercise to give professional substance to the European medical names in India. I have not said anything about the state of Ayurvedic and Unani medicine in India. This is not so much because of lack of space as because of ignorance. I hope that the information furnished here concerning about the European medical men in India up to the middle of the eighteenth century will stimulate an interest in the study of contemporary medical practice in India.

\section{Acknowledgements}

I thank the Nehru Memorial Fund, New Delhi, for the award of a Jawaharlal Nehru Fellowship during 1996-1997 to work on a research project entitled 'Modern science in India: A historical study in the national and global context'. I thank J K Bajaj, Iqbal Khan, Vidyanand Nanjundiah, and $0 \mathrm{~m}$ Prakash for helpful conversations.

\section{References}

Ackerknecht E H 1982 A Short History of Medicine (Baltimore: Johns Hopkins University Press)

Chaudhuri S 1970 The myth of the English East India Company's trading privileges in Bengal, 1651-1686; Bengal Past Present 70 287-292

Conrad L I, Neve M, Nutton V, Porter R and Wear A 1998 The Western Medical Tradition 800 BC to AD 1800 (Cambridge: Cambridge University Press)

Crawford D G 1914 A History of the Indian Medical Service 1600-1913, 2 volumes (London: W Thacker and Co)

Dharampal (ed.) 1983 Indian Science and Technology in the Eighteenth Century. Some Contemporary European Accounts (Hyderabad: Academy of Gandhian Studies)

Grove R H 1996 Green Imperialism Colonial Expansion, Tropical Island Edens and the Origins of Environmentalism 1600-1860 (Cambridge: Cambridge University Press)

Elgood C 1951 A Medical History of Persia and the Eastern Caliphate from the Earliest Times until the Year A.D. 1932 (Cambridge: Cambridge University Press)

Harrison, M 1994 Public Health in British India Anglo-Indian Preventive Medicine 1859-1914 (Cambridge: Cambridge University Press) 
Kochhar R K 1992 Science in British India. 1. Colonial tool', Curr. Sci. 63 689-94

Kochhar R 1999 Education and training in basic space science . and technology. Background material for UNISPACE III, Vienna 19-30 July

Markham C 1913 Colloquies on the Simples and Drugs of India by Garcia da Orta (London: Henry Sotheran and $\mathrm{Co}$ )

Prakash Om 1985 The Dutch East India Company and the Economy of Bengal i630-]720 (Princeton: Princeton University Press)

Prakash Om 1998 European Commercial Enterprise in Pre- colonial India (Cambridge: Cambridge University Press)

Ray N R 1986 Calcutta The Profile of a City (Calcutta: K P Bagchi and Co)

Sharma S R (n.d.) Mughal Empire in India, tenth edition (Agra: Lakshmi Narain Agarwal) 